\section{Kastamonu Eğitim Dergisi Kastamonu Education Journal}

Temmuz 2019 Cilt:27 Sayı:4

kefdergi.kastamonu.edu.tr
Başvuru Tarihi/Received: 18.12.2017

Kabul Tarihi/Accepted: 15.12 .2018 DOI: $10.24106 /$ kefdergi. 2479

\title{
Öğretmenlerin Anlam, Meslek Sürdürme, Stres ve Tükenmişlik Durumlarının Ruhsal Yaşamları Yönünden Değerlendirilmesi
}

\section{Evaluation of Teachers' Meaning, Job Continuity, Stress and Burnout Situations in terms of their Spiritual Lives}

\author{
Öz \\ Ahmet GÖÇEN ${ }^{1}$
}

Ruhsallık, yönetim çalışmalarında giderek artan bir ilgi ile karşılanmış ve son yıllarda işyeri ruhsallığı kapsamında yeniden incelenmeye başlanmıştr. Bu çalışmanın amacı öğretmenlerin hayat anlamını, mesleği sürdürme isteklerini, stres ve tükenmişlik durumlarını ruhsal yaşam ve inançları bağlamında incelemektir. İşyeri ruhsalığı çerçevesinde yapılan bu çalışma nitel araştırma yöntemi temelli olup olgubilim desenindedir. Çalışma grubunun seçiminde uygun örneklem kullanılırken verilerin analizinde içerik ve betimsel analiz tekniklerine yer verilmiştir. 10 öğretmen ile gerçekleştirilen yarı yapılandırılmış görüşmeler sonucunda öğretmenlerin ruhsal yaşamının "insani değerler, insan hakları ve görevsel değerler" temalarında okul hayatlarına etkilerinin olduğu görülmüştür. İş stresine ve tükenmişliğe karşı öğretmenlerin ruhsal ve alternatif çözümler geliştirdiği ifade edilmiştir. Öğretmenlerin hayatlarını anlamlandırmada çocuk sahibi olmadan mutluluk duygusuna kadar farklı olguların rol oynadığı anlaşılmıştır. Katılımcılar genel olarak mesleklerini sürdürmeye istekli olsalar da hayatlarında en az bir kez meslekten ayrılmayı düşündüklerini ifade etmiştir. Bu bulgular genel olarak ele alındığında öğretmenlerin iç yaşamlarının okul hayatlarına önemli etkilerinin olduğunu göstermektedir.

Anahtar Kelimeler: İşyeri ruhsallığı, Öğretmenlik, Stres, Tükenmişlik, , Hayat Anlamı

\section{Abstract}

Spirituality has attracted an increasing attention throughout management studies and been studied under spirit at work in recent years. The purpose of study is to examine teachers' meaning of life, desire to pursue teaching profession, stress and burnout situations in the context of their spiritual life and beliefs. This study within workplace spirituality is based on qualitative research method with a phenomenological design. Convenience sampling was employed in the selection of the study group while content and descriptive analyses were used in the data analysis. As a result of semi-structured interviews with 10 teachers, it was seen that the effects of teachers' spiritual life on school life were gathered within the themes of "human values, human rights and duty values". Teachers were stated to develop spiritual and alternative solutions against job stress and burnout. It is understood that different phenomena like having children, happiness play a role in life meaning of teachers. Although most of the participants seemed willing to pursue their occupation, they thought of leaving the profession at least once in their lives. These findings generally show that teachers' inner lives have a significant impact on their school life.

Keywords: Workplace Spirituality, Teaching, Stress, Burnout, Life Meaning 


\section{Extended Abstract}

Spirituality has attracted the attention of management circles with the introduction of workplace spirituality. In personal sense, spirituality involves the formation of a universal bond with one's inner and outer world, the realization of one's beliefs, the satisfaction with the inner world, and the establishment of bonds of love and respect beyond the self. In organizational context, Mitroff and Denton (1999) describes spirituality as "finding one's ultimate goal in life, establishing a strong connection with colleagues, other people and with the universe, and accommodating personal beliefs and values of workplace." In this regard, workplace spirituality can be defined as an understanding that allows people to find meaning at work with a sense of serving a superior purpose and encourages people listen to their inner voice, to experience transcendence and a sense of integrity among team members.

This study, conducted in 2017-2018 academic year with 10 teachers, examined effects of spirituality at work, solutions for stress and burnout in school life, teachers' life meaning and desire to pursue the teaching profession. Phenomenology design was employed within the framework of qualitative research method. Phenomenology design focuses on phenomena which we are aware of but do not have in depth information about (Yıldırım and Şimşek, 2008). This study on spirituality included four main questions to be addressed by the participants during semi-structured interviews, who were selected in accordance with convenience sampling method. The questions were about 1) the effects of teachers' spiritual life on their work and school life, 2) teachers' spiritual solutions against stress/burnout in school, 3) teachers' meaning and purpose of life, 4) teachers' desire to maintain their profession. In the analysis of the data, content analysis was done for the first three questions while descriptive analysis was done for the fourth question which included mostly short answers. In the content analysis, the themes were formed based on the coded data and presented in tables with direct quotations placed under.

The teachers in the study explained the effects of their spiritual life on their work within the scope of "human values, human rights and duty values". 8 out of 10 participants emphasized the direct effect of spirituality in their school life, and 2 participants did not relate their work to their beliefs. Teachers expressed that their spiritual beliefs help them to be honest, fair, hardworking, compassionate, and guided in the context of "human values". It is understood that the spirituality of the teachers affect them in acting equitably towards the students within "human rights" and forming "duty values". Teachers' spiritual life was found to help them strengthen their human values based on "conscience, equality, justice, honesty, diligence, compassion, avoiding from mistakes, auto control" in schools and they paid more attention to human rights. Teachers emphasized the role of their spiritual life as "a guide", "a support for employee's neatness and order" along with "a support for doing the best in the job" under the theme of "duty values".

In terms of teachers' spiritual solutions against stress/burnout in school, teachers mentioned their solutions within spiritual sources and alternatives. The spiritual solutions of the teachers against negative effects were mostly "Praise, Praying, Patience, Leaving it up to fate etc." while the alternative solutions of teachers against stress and burnout included "Rest/Taking a Break, Empathic behavior, Smile etc.".

Teachers' life meaning was found be gathered under two themes: "the self and beyond the self". The theme about "beyond the self" included mostly "raising children, facts of creation and creating difference for human life" while "the self" included codes like "peace, happiness, beautiful memories, being in a beloved school", money being citied just once among other codes.

During the study, participants were asked whether they had ever thought about quitting their job. 6 out of 10 participants were seen to have thought of this at least once in their life. But, these were seen to be caused by "the feeling of being a mother, the desire to work in other sectors, tiring school program, social value of the job and school based problems". The participants seemed willing to maintain their occupation for long time despite these problems.

All professions are affected from factors like stress, burnout, mobbing, external pressure etc. This study examined the effects of teachers' spiritual life on stress and burnout and their life meaning. Further studies on spirituality can include teachers' inner and outer motivational strength sources against negative or devastating effects in their school life and present more overarching models of solutions against stress and burnout problems in educational organizations. When a holistic understanding of spirituality develops in the workplace, spirituality can play a positive role by increasing resistance to the negative sources at work. Teachers' resistance against school problems can be increased by enriching their life meaning and calling towards their profession. Spirituality in organizations can help people fight against stress and burnout with the power of life meaning and inner sources they experience. 


\section{Giriş}

Ruhsallık, kişinin dış ve iç âlemiyle evrensel bir bağ kurmasını, inandığı şekilde yaşamasını, iç dünyasını tatmin etmesini ve çevresiyle benlik ötesi bağlar kurmasını içerir. Mitroff ve Denton (1999) çalışma ortamındaki ruhsallığı "kişinin hayattaki nihai amacını bulma, çalışma arkadaşlarıyla, diğer kişilerle ve evrenle güçlü bir bağlant kurma ve kendi inançları ile işyeri değerleri arasında uyum sağlama ve anlam" kapsamında açıklamıştı. Ruhsallık örgütsel bir kaynak görevi görür (Bell ve Taylor, 2003). Ruhsallık genellikle neşe, huşu, hüzün, şükran vb. kişiye ait duygular içerse de kişinin kendisinden daha üstün olan bir şeye odaklanması ve bağlanma isteği içermesi yönüyle de kişisel öznelliği aşmaktadır (Heelas, Woodhead, Seel, Tusting, \& Szerszynski, 2005). Ruhsallık çalışma ortamı açısında öznel açıdan birer iç destek ve motivasyon kaynağı olması yanında kişiyi aşan toplumsal veya inanış şekilleriyle işe anlam veren ve iş yapma şeklini, gücünü derinden etkileyen bir olgudur.

Genel olarak öznel algılanan ruhsallık kavramı son zamanlarda özellikle işyeri ruhsallığı bağlamında yönetimsel açıdan incelenmeye başlanmıştır. İşyeri ruhsallığı çalışanların işyerinde üstün bir amaca hizmet etme bilinciyle işte anlam bulmalarına olanak sağlayan, insanların arayışta olmalarını, iç seslerini dinlemelerini, kişiler arası bütünlük ve aşkınlık hislerini destekleyen bir yönetim veya çalışma anlayışı olarak tanımlanabilir. Okullarda işyeri ruhsallığı eğitim ortamının sağladığı evrensel değerler doğrultusunda belli düzeyde yer edinebilmiştir, fakat kurum kültürünün tam bir parçası olabilmesi için okul liderlerinin veya üst politika yapıcılarının işyeri ruhsalığını örgütün doğal bir boyutu olarak görmeleri ve çalışma anlayışını okul çalışanlarının ruhsal ilkeleri lehine şekillendirmeleri gerekir. Bu çalışma ortamının şekillendirilmesinden kasıt iş yerinde tüm çalışanların anlam, aşkınlık ve bütünlük duygularının pekiştirildiği bir çalışma ruhu inşa etmektir.

Sağlıklı bir çalışma ruhunun inşası için liderler, çalışanların işe karşı yükledikleri anlam duygularını güçlendirmelidir; çünkü esnekliğin ve işler arası geçişlerin son derece artı̆̆ bu zamanda çalışanlar artık anlamlı ve ilham veren bir iş arzulamaktadır (Fairholm, 1996). Öğretmenler her çalışanda olduğu gibi işlerinde bağılıı, bütünlük hissi, ilham ve anlam arayışı içindedir. Bu ruhsal boyutları iş hayatına dahil edebilen öğretmenler öz-yansıtmaya daha yatkın. Kendi içsel dünyaları, başkalarıyla ve benlik üstü bir güç ile ilişkilerinde daha önemseyici olmakta ve bu öğretmenlerin kararları empati, mütevazilik ve sevgi çerçevesinde şekillenmektedir (Klerk-Luttig, 2008). Ruhsal tatminin ve anlam, bütünlük vb. ruhsal boyutların olmadığı bir iş ortamında öğretmenler kurum içi sorunlar yaşayabilmektedir. Dağlı ve Ardıç (2016) mevcut çalışma çerçevesinde herhangi bir örgütte çalışanların arzu ve ihtiyaçlarını dikkate almaksızın başarıyı yakalamanın, sürdürmenin ve kurum sağlığını koruyabilmenin nerdeyse imkânsız olduğunu vurgulamaktadır.

İşyerine ilişkin ihtiyaçlardan biri de çalışanların kendi ruhsallıklarını yaşayabilecekleri ve çekinmeden seslendirebilecekleri bir yapıya sahip olmalarıdır (Oliveira, 2004). Bu yapının olduğu okullarda işyeri ruhsallığı okul problemlerini çözmede önemli bir görev görebilir (Göçen \& Özğan, 2017). Çalışanlara ruhsal gelişim firsatları sunan kurumlar, sun(a) mayanlardan daha iyi işleyiş göstermektedir (Konz \& Ryan, 1999). Bu açıdan örgütler çalışanların ihtiyaçlarını tatmin ettiği ölçüde başarılı olabilmektedir. Çalışanın işyerinde iç dünyasının kabul görmesi ile örgüte olan bağlılı̆ı artmaktadır (Rego \& Pina e Cunha, 2008, s. 53). Bu sonuca dayanarak Cline (2015, s. 73) ruhsallıktan yoksun okulların, öğretmenlerin okul örgütüne ilişkin duygusal bağlılıklarını negatif şekilde etkileyeceğini ve öğretmenin okul bağlıığına zarar vereceğini belirtmiştir. Duchon ve Plowman (2005) aynı şekilde işyerinde ruhsallığı göz ardı etmeyi insan olma gerçeğini görmezden gelmeyle eş tutmuştur.

İnsanlar bedeniyle aklıyla ve ruhuyla bir bütünlük gösterir. Bu nedenle öğretmenlerin ve öğrencilerin iç dünyalarını veya ruhlarını, bedenleri ve akılları ile girdikleri okul kapısında bıraktıklarını söylemek veya bunu beklemek gerçekçi olmayacaktır. Lips-Wiersma ve Mills $(2002$, s. 183) de ruhsallığın işyerinde her zaman var olduğunu belirtmiş; fakat çalışanların kendilerini bu konuda güvende hissederek ifade edip edemeyecekleri konusunun bir sorun olarak durduğunu eklemiştir. Liderler bu açıdan kurumdaki bireysel inançları ve ortak fikirleri hoşgörü ile karşılamalı ve uygulamada çalışanlara özgürlük sunmalıdır; bu şekilde çalışanlar ruhsal yolculuğunda kendilerini güvende hissedecektir (Baloğlu \& Karadağ, 2009).

\subsection{Okullarda Stres ve Tükenmişliğe Karşı Ruhsallık}

Öğretmenlik en stresli mesleklerden biridir (Chudzicka-Czupała vd., 2014). Öğretmenlik mesleğinde, özellikle ilk yılında işten ayrılanların oranı dikkat çekmektedir (Farber, 2015). Cemaloğlu ve Şahin (2007)'e göre öğretmenler, meslek seçimi, iş koşulları, boş zaman etkinlikleri ve ekonomik şartlar dikkate alındığında yüksek düzeyde tükenmişlik gösterebilmektedir. Ajala (2013)'ya göre stres, tükenmişlik vb. sorunlar ruhsallık ile çözülebilir ve çalışanların iyilik durumuna katkı sağlayabilir. Cemaloğlu ve Şahin $(2007$, s. 483) yaptıkları araştırmada öğretmenlerin tükenmişlik düzeyi ve manevi doyumları arasında bir ilişki olduğunu saptamış ve şunu ifade etmiştir: "Öğretmenlerin manevi doyumları azaldıkça 
tükenmişlik düzeyleri artmaktadır." Nitekim araştırmacılar, bu durumun mesleğinden manevi anlamda yeteri kadar doyum alamayan öğretmenlerin fazla stres yaşamaları, zevk ve heyecan duymamaları, performans düşüklüğü gibi sebeplerden oluştuğunu eklemiştir. Bu açıdan ruhsallık okul hayatında önemli bir iş tatmini unsuru olarak değerlendirilebilir.

Cook (2017)'a göre ruhsallık öğrenci performansında, öğretmen stres ve tükenmişliğinde etkilere sahiptir. Barsh (2015) öğretmenlerin ruhsallığı hakkındaki çalışmasında öğretmenlerin yaşamla ilgili aşkın inançlarının "öğrenci katılımını" doğrudan etkilediğini ve hem öğretim stratejileri hem de sınıf yönetimi üzerinde dolaylı etkileri olduğunu ortaya koymuştur. Ruhsallık ve öğrenci katılımı/ilgisi arasındaki ilişkiyi Silvern (2006), Peters, (2010), Fry ve Altman (2013) da doğrulamaktadır. Ruhsallık ve boyutları öğretmenlerde strese karşı korunma ve öz yeterlik konusunda etkili bir olgudur (Stanley, 2011; Barsh, 2015; Cook, 2017). Özğan, Bulut, Bulut ve Bozbayındır (2013) öğretmenlerin ruhsal liderlik algıları ile motivasyonları arasındaki ilişkiyi araştırdıkları çalışmalarında, öğretmenlerin motivasyonları ile ruhsal liderlik algıları arasında yüksek düzeyde pozitif yönde anlamlı bir ilişki olduğunu ifade etmişlerdir.

Stresin ve tükenmişliğin oluştuğunun hissedildiği okullarda, okul yönetimince program dâhilinde zamana yayılmış işyeri ruhsallık etkinlikleri uygulanabilir (Göçen, 2017). İşyeri ruhsallık programları sadece huzur, neşe, mutluluk, bağlılık ve iş doyumu gibi kişisel faydalar getirmekle kalmayıp aynı zamanda işe gelmeme, işi bırakma durumları, üretimde durgunluk gibi problemlerin ortadan kalkmasını sağlamaktadır (Kouzes \& Posner, 1995; Paloutzian, Emmons \& Keortge, 2003; Giacalone \& Jurkiewicz, 2003; Fry, 2003). Nitekim ruhsallı̆ın, kişinin sorunlarında, belirsizlik veya zorlu dönemlerinde içsel bir güç ve destek işlevi gördüğü kabul görmektedir (Csiernik \& Adams, 2002).

\section{2. Çalışmanın Önemi}

Maslow'a göre (2001, s. 11) "Freud bize psikolojinin sayrıl (hastalıklı) yönünü gösterdi ama artık sağlıklı yanını da açığa çıkarmamız gerekiyor". Bu nedenle eğitim kurumlarında öğretmenlerin mesleki bağlıığına zarar veren durumlara karşın insanın saf tarafi olan ruhsalığın işyeri bağlamında irdelenmesi ve öğretmenleri ayakta tutan anlam ve aşkınlık duygularının incelenmesi önemlidir. Seyyar ve Evkaya (2015)'ya göre çalışma hayatına dönük ruhsallık ile ilgili araştırmaları güçlendirmek, kendi gelenek ve kültürümüze uygun işyeri ruhsallığı modelleri geliştirmek ve bunları uygulamak bilim insanlarının, sendikaların ve kurumların sorumluluğu altındaki önemli bir görevdir. Bu açıdan günümüz örgütleri, insan ruhunu beslemenin ve tatmin etmenin öneminin farkına varmalı ve işyeri çevresini geliştirecek değerler ve ruhsallık merkezli bir anlayışı sosyal sorumluluk olarak kabul etmelidir (Kurtar, 2009). Okullar da, çalışma gruplarıyla öğretmenlerin ruhsal olarak motivasyonlarını artırıcı bir yönetim anlayışı için çaba sarf etmelidir. Bu açıdan öğretmenlerin okullarda stres, tükenmişlik vb. durumlarına karşı ruhsal motivasyonlarının incelenmesi öğretim hayatına önemli katkılar sağlayabilir.

\subsection{Araştırmanın Amacı}

Yukarıda belirtilen bilgiler ışığında çalışmada öğretmenlerin ruhsal hayatlarının işyerindeki etkilerini, anlam bilincini, mesleği sürdürme isteğini ve stres kaynaklarına yönelik çözümlerini incelemek adına 4 soruya cevap aranmıştı:

1. Katılımcıların ruhsal yaşamlarının iş hayatına etkisi (varsa) nelerdir?

2. Katlımcıların iş stresine karşı geliştirdiği ruhsal çözümler ve alternatifler nelerdir?

3. Katılımcılar açısından hayatın anlamı ve amacı nelerdir?

4. Katlımcıların mesleği sürdürme/terk etmeye ilişkin görüşleri nelerdir?

\section{Yöntem}

\subsection{Model}

Öğretmenlerin iş hayatındaki stres, sorun ve tükenmişliğe çözümlerini, mesleği sürdürme, anlam durumları ve ruhsalığın etkilerini irdeleyen bu çalışma nitel araştırma yöntemi temelli olup olgubilim desenindedir. Olgubilim deseni, farkında olduğumuz ancak derinlemesine sahip olmadığımız olgulara odaklanmaktadır (Yıldırım \& Şimşek, 2008).

\subsection{Veri Analizi}

Çalışmada Miles ve Huberman'ın (1984'den akt: Özdemir, 2010, s. 329 ) nitel veri analizi süreci üç basamakta takip edilmiştir. Bu basamaklardan ilki "verilerin azaltılması", ikinci basamağı "verilerin görsel hale getirilmesi" ve son basamağı da "sonuca ulaşma ve teyit etmedir". Verilerin analizinde ilk 3 soru için içerik analizi yöntemi, son soru için evet hayır cevaplarını kapsayan betimsel analiz kullanılmıştır. İçerik analizinde katılımcılardan toplanan ve yazıya aktarılan veriler düzenlenerek kodlanmış, kodlanan verilerden temalar oluşturulmuş, sonrasında bulgular tanımlanmış ve yorumlanmıştır (Yıldırım \& Şimşek, 2008, s.228). Betimsel analizde (4. soruda) soruya verilen olumlu veya olumsuz (ben- 
zer anlamlı ifadelere göre) sonuçlar tablolaştırılmış sonrasında ilgili ifadeler doğrudan alıntılanmıştır. Çalışmada alıntılar olduğu gibi aktarılmış, çalışma sonuçları tablolar ve açıklamalar ile birlikte verilmiştir. Ayrıca etik nedenlerden dolayı ruhsal/inanç kelimeleri çalışma başlangııında detaylı açıklanmış, bu kavramların çalışmada spesifik bir düşünce sistemine işaret etmediği, kişinin kendi anlayışına göre değişebileceği belirtilmiştir. Katılımcılardan soruları yorumlarken cevapları dini anlayışa, kişisel inanç şekline ya da salt kendi öznel inanışına, ruhsal pratiklerine uygun şekilde "ruhsal yaşam/inanç" kelimeleri altında açıklamaları istenmiştir.

\subsection{Veri Toplama Aracı}

Veri toplamak için çalışmada yarı yapılandırılmış görüşme formu kullanılmıştır. Literatür taraması ve uzman görüşleri sonucu oluşturulan yarı yapılandırımış açık uçlu sorular katılımcılara yansız olarak yöneltilmiş, elde edilen veriler araştırmacı tarafindan analiz edildikten sonra bağımsız uzman değerlendirmesine sunulmuştur ve uzman görüşleri doğrultusunda çalışma bulguları düzenlenmiştir. Çalışma kapsamında katılımcılara a) kişisel inançlarının işlerindeki rolü, b) okulda stres/tükenmişliğe karşı ruhsal kaynakları c) hayatın anlamı ve amacı, d) mesleği sürdürme istekleri hakkında sorular yöneltilmiştir.

\section{4. Çalışma Grubu}

Çalışma grubunun seçiminde uygun örneklem kullanılmıştır. Uygun örnekleme, araştırmacının kolaylıkla ulaşabileceği örneklemi içerir (Özen \& Gül, 2007, s. 413). Araştırmacı ilk önce araştırma hakkında detaylı bir mail hazırlamış, sorular hakkında ve konunun amacı hakkında bilgi vermiştir. Sonrasında bu konuda bilgi toplamak için araştırmacı 20172018 eğitim yılı ilk döneminde Şanlıurfa merkezindeki 3 okulda görev yapan 1 Rehber, 1 İngilizce ve 1 Fen öğretmenin desteğiyle formu mail ortamında katılımcılara göndermiştir. Bu şekilde maile olumlu dönen 10 öğretmen ile yazılı olarak çalışma gerçekleştirmiştir. Çalışmada katılımcılara kendilerini daha rahat açıklamaları için isim, bilgi vb. vermelerine gerek olmadığı belirtilmiş ve formda katılımcıların kendi istekleri haricinde kişisel bilgi vermesini gerektirecek bölüme yer verilmemiştir. Veri analizi aşamasında 10 öğretmen katılımcı kısaca K1, K2... K10 şeklinde kodlanmıştı. Sadece 4 öğretmen kendini tanımlayıcı bilgi vermiştir. K1= Kadın, Ortaokul, Rehber Öğretmeni. K7= Erkek, Lise, İngilizce Öğretmeni. K9= Erkek, (Özel)Lise/Ortaokul, İngilizce Öğretmeni, K10= Kadın, Ortaokul, Fen Öğretmeni. Araştrrmacının kişisel bilgilerin gizliliğini ve görüşlerde çeşitliliği sağlamak üzere okullardaki öğretmenlerden kişisel bilgi talep etmeden bilgi toplaması çalışmada belli sınırlılıklara sebep olmuştur. Bu durum katılımcıların yorumlarının cinsiyet vb. bilgiler doğrultusunda toplu değerlendirilmesini engellemiştir.

\section{Bulgular}

Bulgular kapsamında "öğretmenlerin ruhsal yaşamının okul hayatına etkileri, öğretmenlerin iş stresine karşı ruhsal çözümleri ve alternatifleri, öğretmenler açısından hayatın amacı ve anlamı, mesleği sürdürme durumu" tablolar ile yorumlanmıştir.

Tablo 1. Öğretmenlerin Ruhsal Yaşamının Okul Hayatına Etkileri

\begin{tabular}{lll}
\hline Tema & Kodlar & $\mathrm{f}$ \\
\hline & Vicdan & 3 \\
& Eşitlik ve adalet & 1 \\
& Dürüstlük & 1 \\
\multirow{3}{*}{ Insani Değerler } & Çalışkanlık & 1 \\
& Sevgi & 1 \\
& Merhamet & 1 \\
& Yanlıştan kaçınma & 1 \\
& Otokontrol & 1 \\
\hline \multirow{2}{*}{ Insan Hakları } & Kul(İnsan) hakkı & 4 \\
& Ezilenlerin sesi olmak & 1 \\
\hline \multirow{3}{*}{ Görevsel Değerler } & Derli toplu olma & 1 \\
& Görevi en iyi şekilde yapma & 1 \\
& İşaret görevi sağlama & 1 \\
\hline
\end{tabular}

Yarı yapılandırılmış görüşme formu ile öğretmenlerin inançlarının ruhsal yaşamlarının iş hayatına ne tür etkilerinin olduğu sorulmuş ve katılımcıların bu etkileri "insani değerler, haklar ve göreve ait değerler" kapsamında değerlendirdikleri görülmüştür. 10 katılımcıdan 8'i ruhsal anlayışların iş hayatında doğrudan etkisinin olduğunu vurgularken, 2 katılımcı iş yapışları ile inançlarının doğrudan ilişkili olmadığına değinmiştir. Öğretmenler görüşmelerde genel olarak 
vicdan duygusundan, kul hakkından, ruhsal yaşamlarının görevlerinde derli toplu olmalarına kadar üç temaya vurgu yapmıştir. Öğretmenlerin sahip oldukları inançlar ve düşünceler insani değerler kategorisinde, vicdan olgusunda $(f=3)$ yoğunlaştğı görülmüştür. K2 "Inancım iş hayatımda kesinlikle çok etkili. Vicdanımın rahat olması ve kazandığım parayı sonuna kadar hak ettiğimi bilmek benim için olmazsa olmaz" şeklinde görüş belirtirken; inancının, ruhsal değerlerinin iş hayatında "olumlu etkisinin var olduğunu" ifade eden K1 de "hiçbir meslekte olmayan vicdan muhasebesinin" öğretmenlik mesleğinde olduğunu vurgulamış ve "inancım gereği kul hakkına dikkat ediyorum vicdan muhasebesi yaparak hatalardan kaçıyorum" şeklinde görüşlerine ekleme yapmıştır.

Öğretmenler ayrıca sahip oldukları inançların, insani değerler kapsamında dürüst, adil, çalışkan, merhamet sahibi ve yanlıştan kaçınmalarına yardımcı olduğunu ifade etmiştir. K7 kısaca "Inancım büyük derecede iş hayatımda dürüst ve çalışkan biri olmamda rol oynar" şeklinde görüşünü ifade etmiştir. K6 aslında kendi inandığı hayatla uyumlu yaşamaya özlem duyduğunu belirtmiş ve içsel geliştirdiği insani değerler, hak bilinci ve görevsel değerlere attfa bulunarak şunlara değinmiştir: "şahsi olarak benim için eşitlik, adalet gibi şeyler davranışlarımı olumlu etkiler....inançlarım ile tam tamına bağlı yaşamayı umut ederdim ama yapamıyorum en azından kul hakkı, adalet, merhamet bunlara önem gösteriyorum....empatisi yüksek bir insan olarak bu yönde davranmaya ve ezilenlerin sessiz çığığını az da olsa duyurmaya çalışıyorum.” K4 de görüşlerini şöyle ifade etmiştir: “...sosyal rollerimde kimsenin kul hakkına girmemeye çalışıyorum... Kul hakkı konusunda okuldaki işimde çok huzurluyum."

Görevsel değerler boyutunda öğretmenler sahip oldukları ruhsal yaşam şeklinin "işte yön gösterici olmasındaki rolüne" ve "çalışanların derli toplu olmalarına, görevini en iyi şekilde yapmalarına" değinmiştir. K6 da ruhsal değerlerin iş hayatnna yön vermesi üzerinde durarak eklemiştir: "Kul hakkı, adalet, merhamet bütün bunlar iş yaşamımım konusunda da yön verici oluyor". K4 ise inanç ve görev bilincine ilişkin "inancım elbette etkili. Yaptiğım her iş eksiksiz, derli toplu olmalı aynı özel hayatımdaki gibi. O yüzden derslerde çok yoruluyor oturup defter bile yazmaya firsat bulamıyorum" diyerek görüş belirtmiş, fakat bazen kurum eksenli durumların stres kaynağı olabileceğini eklemiştir. Bu açıdan ruhsal değerler ile çakışan sosyal olayların daha büyük stres kaynağı oluşturabileceği söylenebilir.

Tablo 2. Öğretmenlerin Stres ve Tükenmişliğe Karşı Çözümleri

\begin{tabular}{lll}
\hline Tema & Kodlar & $\mathrm{f}$ \\
\hline & Şükür & 3 \\
& Dua etme & 3 \\
& Sabır gösterme & 2 \\
Ruhsal Çözümler & Kadere bırakma & 2 \\
& Olumlu düşünme & 1 \\
& Telkinde bulunma & 1 \\
& Sonuç odaklı düşünme & 1 \\
& Sürdürme isteği & 1 \\
\hline & Dinlenme/Ara verme & 3 \\
& Empatik davranma & 2 \\
Alternatif Çözümler & Gülümseme & 1 \\
& Diyalog Kurma & 1 \\
& Öfke Patlaması & 1 \\
& Yalnız Kalma & 1 \\
\hline
\end{tabular}

Tablo 2'de iki temel tema oluşturulmuştur. Ruhsal çözümler, stres kaynaklarına yönelik olarak bireyin içsel olarak kurguladığı ve bireysel açıdan herhangi bir fiziki değişim olmadan hayata geçirdiği çözümler iken; alternatif çözümler, en az iki kişiyi içeren sosyal ilişkiler, olgular veya son verme, terk etme, fiziksel durumları içeren çözümleri ifade etmektedir. Örneğin dua etme bireysel ve içsel bir durumken; öfke patlaması en az iki kişinin iletişimini içeren bir duruma işaret etmektedir.

İnanç ve ruhsal yaşamı dini bir çerçevede değerlendiren K2 şükür olgusunun stres karşısında önemli bir kaynak olduğunu şu şekilde vurgulamıştr "Allah'a karşı sevgim ve sorumluluğumun sonsuz olduğunu ve bana verdikleri için ne kadar şükretsem az olduğunu hissediyorum ve yaptiğım işi de onun bana bir lütfu olarak görüp kıymetini biliyorum." İnancının veya ruhsal görüşlerinin iş hayatında "pek" bir etkisinin olmadığını bildiren K3 de "iji günde kötü günde şükrederim" şeklinde şükrün ruhsal bir çözüm kaynağı olduğunu belirtmiştir. Dua etme konusunda görüş bildiren K5 aslında ruhsal yaşamını ve iş hayatını doğrudan ilişkilendirmediğini belirtmiştir: "Gündelik koşturmaca arasında herhangi bir ritüele vakit ayıramıyorum ancak kötü bir durumla karşılaştığımda dua ederek rahatlamaya çalışıyorum, işle ilgiliyse inancımın içine karıştığını düşündügüm bir durum olmuyor" demiştir. K2 bu konuda "Tükenmiş hissettiğimde Allah'a sığınıp ondan 
sabır ve güç isterim bu da bana psikolojik bir rahatık sağlar" şeklinde görüş belirtmiştir. Sabırlı olmaya ilişkin olarak K9 da "Ben sabırlı ve inançlı bir bireyim. İ̧̧ bağlamında sinirli olduğum zaman - ki çok çok az sinirleniyorum- karşımdaki insanın bir çocuk olduğunu düşünüyorum, merhamet duygusu olayın önünü kesiyor" şeklinde fikir beyan etmiştir.

K10 stres karşısında ilk önce olumlu düşünmeyi tercih ettiğini ve devamında ise olayları kadere bırakttğını ifade etmiştir: "Eğer tek yönlü bir olumsuzluk yaşıyorsam meseleye iyi tarafindan bakmaya çalışır, her şerde bir hayır vardır ilkesine göre hareket ederim; ama her şeyin üst üste geldiği anlarda ise sıkışır bazen içinden çıkamam. O zamanda demli bir çay demler Yaratana havale ederim" K3 de stres durumlarında "Takdiri ilahi Allah'ın derim" diyerek olayları akışına, kadere bıraktığını belirtmiştir. K8 stres durumunda diğer katılımcılarından farklı olarak öfke patlaması yeğlediğini belirtmiştir: "Bu durumda öfke patlaması yaşamayı tercih ederim. Hesabı yarına koymam en kısa zamanda keserim. Vaktini beklerim ya da vaktini getiririm"

K4 ise sonuç veya işi bitirme odaklı olduğunda ruhsal açıdan rahatladığını ve bunun da stresin önüne geçtiğini belirtmiştir: "Bir anda her şeyi akışına bırakıp rahatlarım diye düşünürken tersine daha gergin oluyorum. Kurtulmanın tek yolu isi bitirmek. O yüzden bitirmeye yoğunlaşıyorum. Boş geçen bir vakit çocukların hakkına girmek gibi geliyor. Manevi olarak huzur sadece sonuç elde ederek oluyor."

Strese ve tükenmişliğe karşı bir bakış açısı geliştirdiğini ifade eden $\mathrm{K} 5$ ruhsal ve alternatif çözümleri de kapsar şekilde "diyalog, ara verme, yalnız kalma ve telkinde bulunmaya" vurgu yaparak şunları belirtmiştir "Okulda iş esnasında stresle baş etmek için inancımı işin içine katmaktansa sorunu çözme odaklı arayışlar içine girerim, problem her ne ise o an erteleyip ya kişi ile(öğrenci/meslektaş/idari kadro/okul personeli) birebir ayrıca diyalog kurarak çözüme kavuşturmaya çalışırım ya da dikkatimi çekecek başka bir şey ile oyalanır bir süreliğine kafamı meşgul ederim, eğer kendimi çok fazla yorulmuş, tükenmiş hissediyorsam da kendime kesinlikle yalnız kalacağım bir ortam yaratır, sorun her ne ise onun dışında hayatla ilgili güzel şeyler düşünmeye çalışıp, daha önce her sorun nasıl geçti ise bunun da geçeceği yönünde kendime telkinlerde bulunurum."

K6 stres karşısında "dinlenme ve ara vermeye" değinerek görüşlerini şöyle ifade etmiştir: "Günlük hayatımda stresle nasıl başa çıkıyorsam mesleğimle de aynı şekilde baş ediyorum. Tükenmiş hissettiğimde de biraz dinlenmek, aradan biraz zaman geçmesi, yeniden enerji depolamama destek oluyor. K7 ruhsal kaynaklarına ek olarak da "kafamı dağıtacak, beni mutlu edecek şeyler yapmaya çalışırım." şeklinde alternatif bir çözüm üretmiştir. Gülümseyerek ve empati yaparak strese karşı içsel kaynak geliştiren K2 şunu belirtmiştir: "Gülümsemenin sadaka olduğunu düşünerek kendimi daha güler yüzlü davranmaya zorluyorum. Bir öğretmen olarak çocukların masum oldukları ve de benden güçsüz oldukları düşüncesiyle kendimi rahatlatiyorum"

\section{Tablo 3. Öğretmenler Açısından Hayatın Amacı ve Anlamı}

\begin{tabular}{lll}
\hline Tema & Kodlar & $\mathrm{f}$ \\
\hline \multirow{3}{*}{ Benötesi } & Çocuk (evlat) yetiştirmek & 4 \\
& Yaratlış hikmeti & 3 \\
& İnsan hayatına fark katmak & 1 \\
\hline \multirow{4}{*}{ Benlik } & Huzur & 3 \\
& Mutluluk & 3 \\
& Güzel anılara sahip olmak & 1 \\
& Para kazanmak & 1 \\
& Sevdiğim okulda olmak & 1 \\
\hline
\end{tabular}

Tablo 3 kapsamında katlımcıların hayatın anlamına ve amacına ilişkin verdikleri cevaplar temalandırılmıştır. Araştırma esnasında verilen cevaplarda anlam ve amaç iç içe geçmiş olarak verildiği için, çalışmada tablo gösteriminde anlam ve amaç ayrımına gidilmemiştir. Nitekim K3 hayatın anlamı ve amacı sorusuna "çocuklarım" şeklinde cevap vermiş, K8 de hayatın anlam ve amacını " huzuru yakalamak" olarak nitelemiştir.

Tablo 3 incelendiğinde benötesi ve benlik adlı 2 farklı temanın oluştuğu görülmektedir. Bu kapsamda benliğin dışındaki kişi, varlık ve olgularla ilişkiyi vurgulayan "Çocuk (evlat) yetiştirmek ( $f=4)$, Yarathlışın doğasını anlamak ( $f=3$ ) ve Insan hayatina fark katmak $(f=1)$ " adlı kodlar benötesi temasında değerlendirilmiştir. Benlik teması ise "Huzur $(f=3)$, Mutluluk ( $f=3)$, Güzel anılara sahip olmak ( $f=1$ ) ve Para kazanmak" ( $f=1)$ adlı öznel yönelimli kodlar kapsamında incelenmiştir.

Benötesine hizmet etmeye ilişkin olarak K5 hayatın amacı olarak "Önceliğim evlatlarımı yetiştirmek ve tıpkı evlatıarım gibi öğrencilerimi iyi yetiştirmek" şeklinde görüş belirtmiştir. K5 devamında hayatın anlamını amacından farkı 
yorumlamış, başkalarının hayatına katkı sağlamak, dokunmak şeklinde ifade etmiştir: "Zorda olan insanların yardımına koşmak ve hayatı birileri için kolaylaştırmak, mesleğim vasıtasıyla bazılarının hayatında, düşüncelerinde, seçimlerinde, hayatlarında iyi yönde değişiklik yapmak için dünya üzerinde var olduğumu düşünüyorum ve bunları yapmak benim için hayatı anlamlı kılıyor".

K10 görüşlerini yaratıcı ile olan ilişkisi bağlamında, yani yaratıışın doğasını anlamaya yönelik açıklamış, anlam ve amacını ayrı tutmuştur "Yokluktan gelip hayatla şereflendirildim... Bu büyük mükâfatın hakkını vermek bu hayatın mânasıdır. Hayatın anlamı O'nu anlamak, amacıysa bu âleme bir eser bırakmaktır. O'nu anlamak için hatmettiğim bir kitapta karşıma çıkan Ziya Paşa beyiti ile bitireyim; Idrâk-i meâli bu küçük akla gerekmez, Zirâ bu terazi bu kadar sıkleti çekmez." K9 da hayatın anlamını ve amacını yaratılıs hikmeti kapsamında aynı doğrultuda açıklamıștı: "Benim şimdiye kadar anladığım hayatın anlamı şöyle. Buraya geldik ama geçiciyiz. Diğer dünya içinde mutlaka çalışmamız gerekiyor. Her iki cihanda da mutlu olmak için yaşıyorken olabildiğince iyilik yapmak ..... bence bu iki dengeyi sağlarsa insanoğlu hayatın anlamını kavramış demektir."

Benlik teması kapsamında kodlar incelendiğinde ise K1 kısaca hayatın anlamını "Ailemle mutlu huzurlu sağıklı yasayabiliyorsam... Mesleğimi sevdiğim bir okulda gerçekleştirebiliyorsam hayatın anlamı bence bu." şeklinde belirtmiştir. K6 hayatın amacını "mutlu olmak ve başkalarını mutsuz etmemek" şeklinde ifade etmiştir. K7 de "Hayatımın amacı mutlu olmak. Anlamı da bahşedilen hayatı güzel anılar biriktirerek yaşamak." şeklinde belirtmiştir. K4 ise hayatın amacı olarak "huzurlu çocuk büyütmeyi" ilk sıraya koyarken ikinci sıraya da "para kazanmayı" koymuştur.

Tablo 4. Öğretmenlerin mesleği sürdürmeye ilişkin görüşleri

\begin{tabular}{ll}
\hline Gruplar & $f$ \\
\hline İşi bırakmayı düşündüm & 6 \\
İşi bırakmayı düşünmedim & 4 \\
\hline
\end{tabular}

Çalışma kapsamında katılımcılara mevcut işini bırakmayı hiç düşünüp düşünmedikleri sorulmuş, 10 katılımcıdan 6'sı mesleği boyunca en az bir kez de olsa işinden ayrılmayı düşündüğünü belirtmiş; fakat bunu "annelik yapamama, yeni iş hayatı kurma isteği, yoğun ders programı, mesleğin toplumsal değeri, okul temelli huzursuzluklar" gibi öznel ve toplumsal sebeplere bağlamışlardır.

K3 anne olarak çocuklarını bebekken her gün başka bir yere bırakmanın vermiş olduğu manevi rahatsızlık sebebiyle istifayı düşündüğünü maddi sebeplerin ise bunu engellediğini belirtmiştir: "Cocuklarımı bebekken el kapısına bırakmak benim istifa düşüncesine sahip olmamı sağladı. Gelecekte yaşanacak maddiyat kaygısı beni bundan alıkoyan sebeptir". K4 istifayı düşünmüş olsa da mesleğine devam etme isteğinin ağır bastığını belirtmiş ve ayrılma isteğine ilişkin görüşlerini şöyle ifade etmiştir: "Okulda verilen bir görevi de en iyi şekilde yapmaya çalışıyorum ama ortak çalıștiğım insanların sorumsuzlukları beni çok yıpratiyor. Her işi kendim yapıyor buluyorum ve çok stres oluyorum. Çocuklarıma icabında daha az vakit ayırıyorum ve kendimi ișe bu kadar adamıș olmam beni mutsuz ediyor. Sanki öğrencilik hiç bitmemiş gibi. Çalışmıyor da okulda öğrenciymişim gibi hissediyorum ve bu öğrencilik daha yıllarca sürecekmiş gibi stresi de şimdiden canımı sıkıyor".

K5 iş anlamında kendini sınırlanmış hissettiğini ve kendine daha uygun yeni bir hayat planı çizdiğini belirtmiş ama planladığı iş ve hayat için biraz daha süreye intiyacı olduğunu ifade etmiştir. K8 mesleğinin değerinin toplum nezdinde düşük olduğu duygusuna sahip olduğunu belirtmiş; ama bu durumda bile bir fark oluşturabilmek için bu mesleği devam ettirme isteğiyle çalıştğını anlatmıştı. Özel okulda çalıştğını belirten K9 mesleğini çok sevdiğini, dersinden keyif aldığını belirtmiş; ama yine de bazen istifayı düşündüğünü şu şekilde açıklamıştr: "Özel sektör olunca insan bazen çok yoruluyor ve o yorgunluğun vermiş olduğu sinirle zaman zaman istifa etmek istiyorum... çalışma saatlerinin çok olması ve okuldaki ögrenci (yaramaz) potansiyelinin yüksek olması bunu düşünmeme sebep oluyor." K10 da istifayı düşündüğünü "kurum bazlı sorunlar" bağlamında şu şekilde açıklamıştı: "Evet düşündüm... Eğer çalıştığınız ortamda huzurlu değilseniz, herkes gibi bırakıp gitmek istersiniz. Ama ben böyle yapmam. lyi insanlar iyi yerlerde olmalı, ortalık kötülere kalmamalı felsefesiyle mücadele edip olumsuzluğu ortadan kaldırmayı yeğlerim. Bu neden beni alıkoyar"

\section{Sonuçlar}

Çalışma temel olarak "ruhsallığın çalışma hayatına etkisi, strese/tükenmişliğe karşı çözümler, hayat amacı/anlamı ve mesleği sürdürme isteği" olmak üzere dört bulgu çerçevesinde şekillenmiştir.

Öğretmenlerin sahip oldukları ruhsal yaşamın iş hayatlarına etkileri kapsamında ruhsallığın "vicdan, eşitlik, adalet, 
çalışkanlık vb." temelli insani değerlerin gelişiminde veya güçlendirilmesinde rol oynadığı görülmüştür. Öğretmenlerin ruhsallıklarııın, öğretmenlerin öğrencilere karşı hakkaniyetli davranmasında ve görevsel değerleri oluşturmasında etkisinin olduğu anlaşılmıştır. Katılımcıların çoğu ruhsal anlayışlarııın ve inançlarının iş hayatında doğrudan etkisinin olduğunu kabul etmiş, davranışlarında önemli rol oynadığını belirtmiştir. Baloğlu ve Karadağ $(2009$, s. 173)'a göre ruhsal değerlere sahip kişiler kurumlarında bir bütünün parçası olması hissiyle takım çalışmasına yatkın, dinleyici, öğrenen, yaratıcı, gelişimci ve geliştirici bir yapıya sahiptir. Bu açıdan vicdan, eşitlik, adalet vb. ruhsal değerlere sahip olan insanların okul davranışlarında buna dikkat etmesi beklenen durumdur. Fox $(1994$, s. 5)'a göre çalışma ruhun ifadesi ve aynasıdır. Kattımcılar bu açıdan inandıkları ve öğrettikleri temel değerleri okul hayatında ruhsal etkiler kapsamında da aynı derecede vurgulamıştır.

Görevsel değerler boyutunda öğretmenler, sahip oldukları ruhsal yaşamın "işte yön gösterici olmasındaki rolüne" ve "çalışanların derli toplu olmalarına, görevini en iyi şekilde yapmalarına" vurgu yapmıştr. Nitekim kurumlardaki kişiler kendilerini ruhsal olarak tanımlasa da tanımlamasa da örgütlerin ortak kabul gören ruhsal değerleri barındırması gerekmektedir. Kolodinsky vd. (2008, s. 467)'ne göre çalışan değerleri ile örgütün ruhsal değerleri hakkındaki algıları arasında güçlü bir ilişki vardır. Özellikle, örgütsel iklimde hissedilen değerleri kabul eden ve benimseyen çalışanlar, örgütleri ve çalışmaları hakkında daha güçlü bir bağlılık hissedecek ve daha iyi tutumlara sahip olabilecektir.

Çalışmada katılımcılar tarafindan doğrudan ifade edilmese de genel olarak ruhsallığı dini temelli yorumlama eğilimi gözlemlenmiştir. Katılımcılarından bazıları ruhsal yaşamı din boyutunda ele alırken bir kısmı da kendi öznel bakış açıları dahilinde ele almıştır. Genel olarak katılımcılar tarafindan çalışmada ifade edilen "dua, şükür, kadere bırakma ve yaradılış hikmeti" gibi olgular dini bir bakış açısıyla ifade edilmiştir. Nitekim din ve ruhsallığın örtüşen kavramlar olduğu hakkında tartş̧malar da süregelmektedir. Zinnbauer, Pargament ve Scot (1999, s. 906)'a göre çoğu insan ruhsallık ve dindarlık terimlerini farklı olarak görmekte, fakat kendilerini hem dini hem de ruhsal olarak tanımlayabilmektedir. Zinnbauer vd. (1997)'leri katılımcılardan dindarlık ile ruhsalık arasındaki ilişkiyi tanımlamalarını istediklerinde katılımcıların çok azı (\% 2,6) "din ve ruhsallığı" aynı kavram olarak belirtmiş, fakat aynı çalışmada katılımcıların çoğu (\%74) kendilerini hem ruhsal hem de dindar olarak tanımlamışlardır. Din ve ruhsallık arasındaki ilişki insan-su metaforu ile açıklanabilir. İnsan bedeninin kişinin yaşına göre \%50-70 arası oranda sudan oluştuğu bilinmektedir, bu durumda insan sudur demek mantık açısından doğru olmasa da gerçeği ifade eden bir mecaz olarak insan sudur veya su ile yoğrulmuştur denebilir. Din ve ruhsallık aynı olmasa da önemli ölçüde birbiriyle bağdaşıktır. Bedel (2009, s.162)'in Türkiye bağlamında ruhsalık üzerine yapmış olduğu ölçek çalışmasında insanların ruhsallığı dindarlıktan farkıı algıladığını fakat çoğunun bu iki kavram arasında doğal bir bağın varlığını kabul ettiğini belirtmiştir.

Çalışmada öğretmenlerin strese ve tükenmişliğe karşı ruhsallık temelli geliştirdiği çözümler incelenmiş; öğretmenlerin stres durumlarında ruhsal ve alternatif çözümler geliştirdiği görülmüştür. Sexton $(2013$, s.94) ruhsallığın, insanlar ve durumlar ile nasıl baş edileceğine dair bir yol haritası sağladığını ifade etmiştir. Çalışma kapsamında da yol haritası olarak "şükür, dua etme, sabır, kadere bırakma" en fazla kullanılan ruhsal çözümler olarak sıralanırken "dinlenme/işe ara verme, empatik davranma" ise en fazla kullanılan alternatif çözüm kaynakları olarak ifade edilmiştir. Nitekim, East $(2005$, s. 137) ruhsal pratiklerin günlük işlerine güç kattı̆ını belirten katlımcıların bulunduğu çalışmasında bu pratiklerin işte stres anlarının yönetimi için etkili olduğunu ve çalışanların yeteneklerini geliştirdiğini ifade etmiştir. Kim ve Seidlitz (2002) çalışması sonucunda ruhsallığa daha fazla vurgu yapmanın insanların stres ile baş çıkmasında önemli bir rol oynayabileceğini ve buna yönelik programların geliştirilebileceğini ifade etmiştir. Bu açıdan şükür, dua, sabır, kadere bırakma, dinlenme/işe ara verme, empatik davranma vb. çözümlerin kişilerin doğasına uygun şekilde entegre edileceği bir program bu konuda faydalı sonuçlar üretebilir. Zaten Gibbel (2010)'in ruhsallık üzerine yapttğı çalışmada da gruplar arası istatistiki olarak anlamlı sonuç çıkmasa da katılımcıların ruhsallık eksenli programdan daha fazla fayda gördükleri, program sonunda daha az strese sahip oldukları ve diğer katılımcılara göre daha fazla pozitif etkilere sahip oldukları belirlenmiştir.

Marshall’ın (2009) öğretmen adaylarının mesleği seçme nedenlerini araştırdığı çalışmada öğretmen adayları, öğretmenliğin onlar için bir amaç ve anlam ifade ettiğini ve bu çağrıyı hissettiklerini belirtmişlerdir. Yapılan bu çalışmada da öğretmenlerin sahip oldukları anlam ve hayatın amacına ilişkin görüşler irdelenmiş, bu kapsamda iki farklı tema altında "çocuk yetiştirmek, yaratılış hikmetini anlamak" ve "huzurlu hayat ve mutluluğu yakalamak" en yüksek frekans değerine sahip kodlar olarak sıralanmıştır. Para kazanmak sadece bir katılımcı tarafindan ifade edilmiştir. Nitekim günümüzde insanlar anlam arayışını daha derinden hissetmekte ve finansal özgürlükten çok anlam aramaktadırlar (Kaya, 2015). Mitroff ve Denton $(1999, \mathrm{s.85})$ çalışmalarında üst yönetim çalışanlarına işinde en çok anlam ve amaç hissi veren durumların neler olduğunu sormuş ve katılımcı cevaplarını 7 basamakta sırasıyla listelemiştir: 1) Kişi olarak tüm potansiyelimi gerçekleştirmek, 2) İyi/etik bir kurumla bağlantılı olmak, 3) ilgi çekici iş, 4) Para kazanmak, 5) İyi dostlar ve insanlığa 
hizmet 6) Gelecek nesillere hizmet, 7) Yakın çevreye hizmet. Bu çalışma sonuçları açısından bakıldığında öğretmenler ve ticari yönetim sektöründe çalışanlar arasında anlam ve amaç açısından bazı farklılıkların olduğu görülmektedir. Öğretmenler çalışmada en fazla kendi çocuklarını ve öğrencilerini yetiştirmeyi hayatın anlamı ve amacı olarak görmüşken; Mitroff ve Denton (1999)'un çalışmalarında öncelik sırası farklıdır.

Çalışmada on kathlımcıdan altısı mesleği boyunca en az bir kez de olsa istifa etmeyi düşündüğünü belirtirken bunu farklı sebeplerle açıklamıştr: "annelik yapamama, yeni iş hayat kurma isteği, yoğun ders programı, mesleğin toplumsal değeri, okul temelli huzursuzluklar" gibi öznel, kurumsal ve toplumsal sebeplerin rol oynadığı görülmüştür. Mckinnon (2009) çalışmasında nitel görüşmeler sonucunda okul sisteminde şefkat ve empati sorununun yaşandığını, eğitimcilerin ruhsal intiyaçlarının dikkate alınmadığını ve kişisel bütünlüklerin genellikle azalmaya yüz tuttuğunu saptamış ve şu şekilde çıkarımda bulunmuştur: "Ruhsallık ve kişisel bütünlük seçenek değil, öğretmen hayatının tam bir gerekliliğidir, ihmal edildiğinde maliyetlere ve eğitim sistemi açısından eksiklilere, öğrenci öğrenmesinde kalite düşüklüğüne sebep olabilir." (s, iv)

İki katılımcı tarafindan vurgulanan "okul temelli huzursuzlukların" temelinde "okul içi ilişkiler ve sorumluluk paylaşımı" olduğu görülürken; diğer katılımcıların vurguladığı annelik, mevcut meslekteki tatminsizlik ve mesleğin toplumsal değeri, yoğun ders programı ve yaramazlık yapan öğrenci profili de okulda stres kaynağı olarak görülmüştür. Nitekim bu sonuçlar okulda mevcut öğretmen tatmininin, okul içi empatik iletişimin ve destek sistemlerin eksikliğini göstermektedir. Öğretmenlerin mesleklerine devam etme ya da bırakmalarıyla ilgili yapılan araştırmalarda öğretmenlerin bu meslekte kalma veya seçme sebeplerinden bazılarını "duygusal açıdan tatmin olmaları, okul içi destek sisteminin var olması ve öğrenci hayatlarında bir farklılık oluşturacaklarına inanmaları" oluşturmaktadır (Johnson ve Birkeland, 2003).

İşyerinde bütüncül bir ruhsallık anlayışı geliştiğinde ruhsalık çalışmada belirtilen kaynaklara ve diğer stres kaynaklarına karşı dayanıklılık artırarak olumlu rol oynayabilir. Strese ilişkin olarak Johnson (2017) korelasyon analizi sonucunda işyerinde ruhsallık ve iş stresinin boyutları arasında istatistiksel olarak anlamlı ilişkiler olduğunu ifade etmiştir. Calicchia ve Graham (2006)'a göre stres ve ruhsal iyilik durumu birçok değişken açısından negatif bir ilişki taşımaktadır. Csiernik ve Adams (2002) çalışmalarında ruhsallığın iyilik durumuna katkı sağlarken işyeri stresine karşı rol oynadığını bulmuştur. Chand ve Koul (2012) işyeri ruhsallığının iş stresi ile başa çıkmada en güçlü yordayıcı olduğunu ifade etmiştir. Walt ve Klerk (2014, s. 379) çalışmasında Nasina ve Doris (2011)'in çalışmasına atff yaparak modern örgütlerin stres kökenli hastalıklar, tükenmişlik, işe gelmeme, şiddet ve bozulma/yozlaşma gibi durumların ruhsallığın olmadığı kurumların karakteri olduğunu ifade etmiştir. Bu açıdan işyerinde güçlü bir ruhsalık bilincinin "hayat ve iş stresini" azalttğı söylenebilir.

\section{5. Öneriler}

Yapılan birçok çalışmada fiziksel, sosyal ve çevresel faktörlerin çalışanlar üzerinde etkisi incelenmiştir. Bu çalışma eğitim örgütleri açısından ele alındığında içsel değerlerin ve inanışların öğretmen hayatını ne derece etkilediğini ortaya koymaktadır. Bu nedenle öğretmelerin stres ve tükenmişliğine karşı alınacak çözümler arasında öğretmenlerin ruhsal yönlerinin, eğitim kurumlarının evrensel değerlere bakan yönlerinin de dikkate alınması gerekmektedir. Çalışma sonuçları açısından değerlendirildiğinde kişilerin sahip olduğu ruhsal yönelimler kişilerin iş hayatında önemli roller üstlenmektedir. Okullarda sağlıklı bir ortamın oluşabilmesi adına idarecilerin her bir öğretmenin ayrı bir ruh taşıdığının farkında olmaları, farklılıkların yönetimi konusunda beceriye sahip olmaları gerekir.

Çalışmada stres ve tükenmişliğe karşı öğretmenlerin dini ve alternatif çözümler ürettiği görülmüştür. Politika yapıcılar tüm inanç sitemlerine saygı çerçevesinde öğretmenlere stres ve tükenmişlik durumunda kapsayıcı eğitim destekleri ve motivasyon kaynakları sunabilir. Bu eğitimlerde sorun anlarında öğretmenlerin sabır duygusunu geliştirme, dinlenme/ara verme, empatik davranma, gülümseme, diyalog geliştirme, olumlu düşünme vb. çözümleri nasıl hayata geçirecekleri anlatılabilir.

Son olarak her meslekte olduğu gibi öğretmenler de stres, tükenmişlik, mobbing, çevresel sorunlar vb. birçok faktörden etkilenmektedir. Bu çalışmada öğretmenlerin olumsuz durumlara karşı geliştirdiği sadece içsel ve anlama bağlı faktörler incelenmiştir. İleriki çalışmalarda öğretmenlerin mesleğinde yaşadıkları psikolojik yıkımlara karşı çevresel, fiziksel, ruhsal ve maddiyata dayalı etkenler toplu incelenerek daha bütüncül bir çözüm önerisi geliştirilebilir.

\section{Kaynakça}

Ajala, E. M. (2013). The impact of workplace spirituality and employees' wellbeing at the industrial sector: the Nigerian experience. Journal of the African Educational Research Network, 13(2), 1-13. 
Baloğlu, N., \& Karadağ, E. (2009). Ruhsal liderlik üzerine teorik bir çözümleme. Kuram ve Uygulamada Eğitim Yönetimi, 15(58), 165-190.

Barsh, R. (2015). Exploring the Relationship between Teacher Spirituality and Teacher Self-Efficacy (Order No. 10014508). Available from ProQuest Central; ProQuest Dissertations \& Theses Global. (1767771569). Retrieved from https://search.proquest.com/ docview/1767771569?accountid=15958

Bedel, G., (2009). The Validity and Reliability Study of the Turkish Version of the Spirituality Scale (Yayımlanmamış Yüksek Lisans Tezi). İstanbul Bilgi Üniversitesi, İstanbul

Bell, E., \& Taylor, S.(2003). The elevation of work: Pastoral power and the new age work ethic. Organization, $10(2), 329-349$. doi:10.1177/1350508403010002009

Calicchia, J. A., \& Graham, L. B. (2006). Assessing the relationship between spirituality, life stressors, and social resources: buffers of stress in graduate students. North American journal of psychology, 8(2), p. 307-320

Cemaloğlu, N., \& Şahin, D. E. (2007). Öğretmenlerin mesleki tükenmişlik düzeylerinin farklı değişkenlere göre incelenmesi. Kastamonu Eğitim Dergisi, 15(2), 465-484.

Chand, P., \& Koul, H. (2012). Workplace spirituality, organizational emotional ownership and job satisfaction as moderators in coping with job stress. Decision Making, 9(10).

Chudzicka-Czupała, A., Chrupała-Pniak, M., \& Grabowski, D. (2014). Why may teachers become cynical at work? Predictors of organizational cynicism among polish teachers-research report. Stanisław Juszczyk, 262.

Cline, P. W. (2015). Organizational Commitment in the K-12 Public School Work Environment: A Workplace Spirituality Perspective (Order No. 3728499). Available from ProQuest Dissertations \& Theses Global. (1746623345). Retrieved from http://search.proquest.com/ docview/1746623345?accountid=15958

Cook, K. L., Jr. (2017). The Impact of Spirituality and Occupational Stress among Middle School Teachers (Order No. 10258984). Available from ProQuest Dissertations \& Theses Global. (1874560832). Retrieved from https://search.proquest.com/docview/1874560832?accountid $=15958$

Csiernik, R., \& Adams, D. W. (2002). Spirituality, stress and work. Employee Assistance Quarterly, 18(2), 29-37.

Dağlı, A., \& Ardıç, T. (2016). Ortaokullarda görevli öğretmenlerin ruhsal liderliğe ilişkin algıları. Electronic Journal of Education Sciences, 3 (5), Retrieved from http://dergipark.gov.tr/ejedus/issue/15935/167566

Duchon, D., \& Plowman, D. A. (2005). Nurturing the spirit at work: Impact on work unit performance. The Leadership Quarterly, 16(5), 807-833. doi:10.1016/j.leaqua.2005.07.008

East, T. J. (2005). A Grounded Study on How Spirituality in the Workplace Impacts a Person's Job Satisfaction (Order No. 3168180). Available from ProQuest Central; ProQuest Dissertations \& Theses Global. (305364697). Retrieved from https://search.proquest.com/ docview/305364697?accountid=15958

Fairholm, G. W. (1996). Spiritual leadership: Fulfilling whole-self needs at work. Leadership \& Organization Development Journal, 17(5), 11-17. doi:10.1108/01437739610127469

Farber, K. (2015). Why Great Teachers Quit and How We Might Stop the Exodus. New York: Skyhorse Publishing.

Fox, M. (1994). The Reinvention of Work: A New Vision of Livelihood for Our Time. San Francisco: Harper Collins.

Fry, L. W. (2003). Toward a theory of spiritual leadership. The Leadership Quarterly, 14(6), 693-727. doi:10.1016/j.leaqua.2003.09.001

Fry, L. W., \& Altman, Y. (2013). Spiritual Leadership in Action: The CEL Story Achieving Extraordinary Results through Ordinary People. Charlotte: IAP.

Giacalone R. A., \& Jurkiewicz C. L. (2003) Toward a Science of Workplace Spirituality. In R. A. Giacalone, C. L Jurkiewicz (Eds.), Handbook of Workplace Spirituality and Organizational Performance. M. E. Sharpe, Armonk, New York, pp. 3-28

Gibbel, M. R. (2010). Evaluating a Spiritually Integrated Intervention for Depressed College Students (Order No. 3424543). Available from ProQuest Dissertations \& Theses Global. (757372637). Retrieved from https://search.proquest.com/docview/757372637?accountid $=15958$

Göçen, A. (2017). Eğitim Kurumlarında Işyeri Ruhsalliğinin Geliştirilmesine Yönelik Deneysel bir Uygulama (Yayınlanmamış Doktora Tezi). Gaziantep Üniversitesi, Eğitim Bilimleri Enstitütüsü, Gaziantep

Göçen, A., \& Özğan, H. (2017). Workplace spirituality: metaphors and opinions of teachers. European Journal of Education Studies. https://www.oapub.org/edu/index.php/ejes/article/view/1185

Heelas, P., Woodhead, L., Seel, B., Tusting, K., \& Szerszynski, B. (2005). The Spiritual Revolution: Why Religion is Giving Way to Spirituality. Oxford: Blackwell.

Johnson, M. K. (2017). The Influence of Workplace Spirituality on WorkStress in Higher Education Employees (Order No. 10264838). Available from ProQuest Dissertations \& Theses Global. (1886474579). Retrieved from https://search.proquest.com/docview/1886474579?accountid=15958

Johnson, S.M., Birkeland, S.E.(2003). Pursuing a "sense of success": New teachers explain their career decisions. American Educational Research Journal, 40(3), 581-617. 
Kaya, A. (2015). The relationship between spiritual leadership and organizational citizenship behaviors: A research on school principals' behaviors. Educational Sciences: Theory and Practice, 15(3), 597-606.

Kim, Y., \& Seidlitz, L. (2002). Spirituality moderates the effect of stress on emotional and physical adjustment. Personality and Individual differences, 32(8), 1377-1390.

Klerk-Luttig, J. (2008). Spirituality in the workplace: A reality for South African teachers? South African Journal of Education, 28(4), 505-517. Retrieved from http://www.scielo.org.za/pdf/saje/v28n4/a04v28n4.pdf.

Kolodinsky, R. W., Giacalone, R. A., \& Jurkiewicz, C. L. (2008). Workplace values and outcomes: Exploring personal, organizational, and interactive workplace spirituality. Journal of Business Ethics, 81(2), 465-480. doi:10.1007/s10551-007-9507-0

Konz, G. N. P., \& Ryan, F. X. (1999). Maintaining an organizational spirituality: No easy task. Journal of Organizational Change Management, 12(3), 200210. doi:10.1108/09534819910273865

Kouzes, J. M. ve Posner, B. Z. (1995). The Leadership Challenge. San Francisco: Jossey-Bass.

Kurtar, Ş., (2009). Ruhsal Liderlik Ölçeği: Türkçe Dilsel Eşdeğerlik, Geçerlik ve Güvenirlik Çalişmasi. (Yayımlanmamış Yüksek Lisans Tezi). Yeditepe Üniversitesi Sosyal Bilimler Enstitüsü, i̇stanbul

Lips-Wiersma, M., \& Mills, C. (2002). Coming out of the closet: Negotiating spiritual expression in the workplace. Journal of Managerial Psycholo$g y, 17(3), 183-202$. doi:10.1108/02683940210423097

Marshall, J. M. (2009). Describing the elephant: Preservice teachers talk about spiritual reasons for becoming a teacher. Teacher Education Quarter$1 y, 36(2), 25-44$. Retrieved from https://search.proquest.com/docview/222879754?accountid=15958

Maslow, A. H. (2001). Insan olmanın psikolojisi. (Çev. O. Gündüz), İstanbul: Kuraldışı Yayınları.

McKinnon, D. (2009). Uncovering and Understanding the Spirituality and Personal Wholeness of School Educators (Order No. NR54475). Available from ProQuest Central; ProQuest Dissertations \& Theses Global. (304832727). Retrieved from https://search.proquest.com/docview/304832727?accountid $=15958$

Mitroff, I. I., \& Denton, E. A. (1999). A study of spirituality in the workplace. Sloan Management Review, 4O(4), 83.

Oliveira, A. (2004). The place of spirituality in organizational theory. EJBO - Electronic Journal of Business Ethics and Organization Studies, 9(2), 17-21, https://jyx.jyu.fi/dspace/handle/123456789/25362.

Nasina, M. D., \& Doris, K. P.P. (2011) . The workplace spirituality and affective commitment among auditors in big four public accounting firms: Does it matter? Journal of Global Management, 2(1), 216-226

Özğan. H., Bulut, L., Bulut, A. \& Bozbayındır, F. (2013). Öğretmenlerin ruhsal liderlik algıları ile motivasyonları arasındaki ilişkinin incelenmesi. Uşak Üniversitesi Sosyal Bilimler Dergisi, 6(1), 70-83

Özdemir, M. (2010). Nitel veri analizi: Sosyal bilimlerde yöntembilim sorunsalı üzerine bir çalışma. Eskişehir Osmangazi Üniversitesi Sosyal Bilimler Dergisi, 11(1).

Özen, Y., \& Gül, A. (2007). Sosyal ve Eğitim bilimleri araştırmalarında evren-örneklem sorunu. Atatürk Üniversitesi Kazım Karabekir Eğitim Fakültesi Dergisi, (15), 395-422

Paloutzian, R.F., Emmons, R.A., \& Keortge, S.G. (2003) Spiritual well-being, spiritual intelligence, and healthy workplace policy. In: R.A. Giacolone and C.L. Jurkiewicz (Eds), Handbook of workplace spirituality and organizational performance, M.E. Sharpe, New York, pp. 123-137.

Rego, A., \& Cunha, M. P. (2008). Workplace spirituality and organizational commitment: An empirical study. Journal of Organizational Change Management, 21(1), 53-75. doi:http://dx.doi.org/10.1108/09534810810847039

Seyyar, A., \& Evkaya, C. (2015). Batıda “işsyeri Maneviyatı” Üzerine Yapılan Bilimsel Çalışmaların Türk Bilim Camiasına Etkileri. Siyaset, Ekonomi ve Yönetim Araştirmaları Dergisi. 143-171

Sexton, N. L. (2013). The Perceived Impact of Spirituality on the Leadership and Careers of Mid-Level Leaders (Order No. 3573686). Available from ProQuest Dissertations \& Theses Global. (1437649344). Retrieved from https://search.proquest.com/docview/1437649344?accountid=15958

Silvern, S.B. (2006). Educating mind and spirit: Embracing a confluence of cultures in the education of children. Childhood Education, 83(1), 2-5.

Stanley, A. Q. (2011). Benefits of teacher 'connections' in stressful educational settings. International Journal of Children's Spirituality, $16(1), 47-58$.

St. Peters, T. R. (2010). The religious spirituality of an indiana public school leader and its influence on the school (Order No. 3404461). Available from ProQuest Central; ProQuest Dissertations \& Theses Global. (516336084). Retrieved from https://search.proquest.com/docview/516336084?accountid=15958

Yıldırım, A. \& Şimşek, H. (2008). Sosyal Bilimlerde Nitel Araştırma Yöntemleri. Ankara: Seçkin Yayıncılık.

Walt, F., \& Klerk, J. J. (2014). Workplace spirituality and job satisfaction. International Review of Psychiatry, 26(3), 379-389.

Zinnbauer, B. J., Pargament, K. I., Cole, B., Rye, M. S., Butter, E. M., Belavich, T. G., Hipp, K. M., Scott, A. B., \& Kadar, J. L. (1997). Religion and spirituality: Unfuzzying the fuzzy. Journal for the scientific study of religion, 549-564.

Zinnbauer, B. J., Pargament, K. I., \& Scott, A. B. (1999). The emerging meanings of religiousness and spirituality: Problems and prospects.Journal of personality, 67(6), 889-919. 